(ISSN - 2752-7018)

VOLUME 02 ISSUE 01 Pages: 35-42

SJIF IMPACT FACTOR (2021: 5. 376)

OCLC -1276789625 METADATA IF -7.569
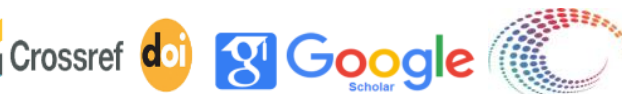

metapata indexing 5) WorldCat" fir MENDELEY

Publisher: Frontline Journals

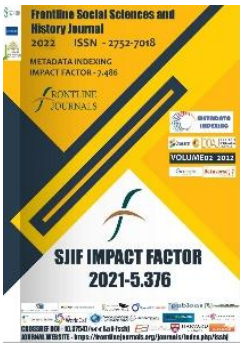

Journal Website: https://frontlinejournal s.org/journals/index.ph $\mathrm{p} /$ fsshj

Copyright: Original content from this work may be used under the terms of the creative commons attributes 4.0 licence.
(6) Rearch Article

\section{LAND RECLAMATION AND IRRIGATION MEASURES OF VIRGIN LANDS IN KARSHI STEPPE}

Submission Date: January 11, 2022, Accepted Date: January 21, 2022,

Published Date: January 31, 2022

Crossref doi: https://doi.org/10.37547/social-fsshj-02-01-05

Oybek Kamilovich Komilov

Doctor Of Sciences In History (Dsc), Professor At The Department “Theory Of Civil Society" Of Andizhan State University, Andizhan Region, Republic Of Uzbekistan

\title{
Abstract
}
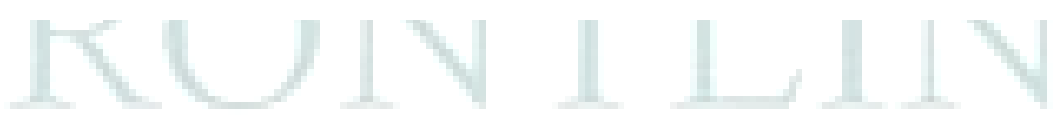

This article is devoted reclamation of virgin land and increase of cotton monopoly in Karshi steppe in the period of Soviet government by the helping archive materials, historical literatures and media materials as well.

\section{KeYwordS}

Karshi steppe, irrigation, reclamation, virgin lands, cotton monopoly.

\section{INTRODUCTION}


(ISSN - 2752-7018)

VOLUME 02 ISSUE 01 Pages: 35-42

SJIF IMPACT FACTOR $(2021: 5 \cdot 376)$

OCLC -1276789625 METADATA IF -7.569

Publisher: Frontline Journals

To begin with, in the period of the Soviet authority, it was aimed to build a colonial and tyrant society in Uzbekistan. First of all, the administrators paid attention to the development of agriculture in the Republic. Because, Uzbekistan being within the former Union specialized to grow cotton, became the source of raw material and $3 / 2$ of the cotton was carried to the center in carrying out it, water and irrigation were important. According to the colonial character of the agrarian policy of the Soviet authority, irrigation and land-reclamation of the Republic developed intensively.

\section{RESEARCH METHODS}

The main purpose of the Soviet Government was to enlarge cotton fields and to increase cotton harvest by developing these fields. A special attention was paid by the tyrant authority to the irrigation construction in the republic, and division of financial means for it also increased year by year. A lot of irrigation structures were constructed to irrigate sowing fields and huge areas.
So, the Soviet government reclaimed a vast area of virgin lands aiming to develop cotton growing in Uzbekistan. This quickened cotton growing branch and at the same time it increased cotton monopoly. This policy caused many bad conditions. The initiative of reclamation of Karshi deserts by the Soviet began in 1960. That is why many families were transferred there in order to complete the reclamation consistently. The First President of the Republic of Uzbekistan, I.A.Karimov described this process as following: "During the whole period of organizational transfer of people to the Karshi deserts, only 600 families moved in there. And nowadays 40 of them settled down there..." [1, p. 35]. Lots of families had to leave the there. Because living condition was hard. Transfer policy of the Soviet caused serious problems in lifestyle of the local people. But the government put forward the goal of reclaiming virgin land in the area. Especially, total area which was to be reclaimed and irrigated in Karshi deserts included 1 million 306 thousand hectares. And 435 thousand hectares of it was in higher zone, 871 hectares in lower zone.

\section{RESULTS AND DISCUSSIONS}


(ISSN - 2752-7018)

VOLUME 02 ISSUE 01 Pages: 35-42

SJIF IMPACT FACTOR $(2021: 5 \cdot 376)$

OCLC -1276789625 METADATA IF -7.569

Soviet government created a lot of kind decrees. It depends on the cotton monopoly. For example, CPCC of Uzbekistan and the Ministers' Council of Uzbekistan SSR determined the following in decree №76 on February, 1961 “on reclaiming measures of the new lands on the basin of Surkhandarya under the base of Surkhan water reservoir concerning irrigation and farming" [2, p.289-290]:

1. "The chief plan of agricultural reclaiming and irrigating the new lands of Surkhandarya province in Uzbekistan SSR under the base of the Southern Surkhan water reservoir" worked out by "Sredashydrovodhlopok" institution was approved and 356 million roubles of capital means were separated to carry out it.

2. The plan of preparation 86,3 thousand hectares of the new lands under the Southern Surkhan water reservoir in Surkhandarya province in the 7-year period was approved. The plan was carried out for 0,5 thousand hectares in 1959, 3,3 thousand hectares in 1961, 11,1 thousand hectares in 1962, 20,6 thousand hectares in 1963, 25 thousand hectares in 1964, 25,8 thousand hectares in 1965.
Basing on the decree №718 "on the measures of enlarging irrigation areas and improving irrigation system techniques in Samarkand, Bukhara and Kashkadarya provinces, increasing provision of irrigation areas with water" by the CP CC of Uzbekistan and the Ministers' Council of Uzbekistan SSR on December 21, 1964, the Irrigation Ministry of Uzbekistan SSR proclaimed order №3 on January 6, 1965.

According to it, the Ministry of production and preparation of agricultural products of Uzbekistan SSR, the Ministry of Irrigation of Uzbekistan SSR accepted the proposal of the executive committees of Samarkand, Bukhara and Kashkadarya provinces on the reclamation of 94 thousand hectares of virgin and new lands in 1965-1970, as well as, it was arranged to enlarge Kattakurgan water reservoir for 27 thousand hectares as the construction of the Amu-Karakul canal in 15 thousand hectares and the Amu-Bukhara canal in 24 thousand hectares and the construction of the Chimkurgan, Pachkamar and Kalkamin water reservoir in 28 thousand hectares-in the suggested provinces[3, p.141]. "Sredashydrovodhoz" institution was responsible for the formation of the project on 
(ISSN - 2752-7018)

VOLUME 02 ISSUE 01 Pages: 35-42

SJIF IMPACT FACTOR $(2021: 5 \cdot 376)$

OCLC -1276789625 METADATA IF -7.569

reclaiming the lands of mid Kashkadarya by December 1, 1965, for the construction of the canals with pumping stations on both banks from the Chimkurgan water reservoir, for generalizing working drafts of general work capacity in 1966.

According to the above mentioned decree №718 "On the measures of enlarging irrigation areas and improving irrigation system techniques in Samarkand, Bukhara and Kashkadarya provinces, increasing provision of irrigation areas with water" by the CPCC of Uzbekistan and the Ministers' Council of Uzbekistan SSR the Ministry of production and preparation of agricultural products of Uzbekistan SSR worked out order №72 on February 6, 1965 [4, p.60].

The Ministry of production and preparation of agricultural products of Uzbekistan SSR worked out order № 98 on February 19, 1965 in accordance with the decree №93 on February 9, 1965 "On increase measures of providing irrigating areas of Uzbekistan SSR in 1965 with water" by the Ministers' Council of Uzbekistan SSR. As the Ministers' Council of Uzbekistan SSR noted, it was expected that water spending was in rather low norm during the vegetation period in 1965.

In total 513,1 thousand hectares of irrigating land was reclaimed in Uzbekistan during the 9th 5-year time period (1971-1975). Particularly, the farms organized in the territory of the new reclaimed areas were specialized to cotton growing. In 1975 5013,3 thousand tons of cotton was gathered and exported to the threshingfloor of the Union. The personnel with secondary-special education also have a particular importance in irrigation development in Uzbekistan. Upbringing the personnel with secondary-special education carried out by 6 irrigation and drainage technical schools within the irrigation Ministry system. For instance, there functioned irrigation and drainage schools in Tashkent, Samarkand, Andizhan, Urganch, Surkhandarya and Nukus. 8496 specialist personnel were prepared in these institutions within 9 five-year terms in the fields of irrigation and drainage, hydro technical construction, mechanization of irrigation and drainage work and auto construction exploitation in irrigation system. There was brought up 1349 young personnel with secondary-special technical 
(ISSN - 2752-7018)

VOLUME 02 ISSUE 01 Pages: 35-42

SJIF IMPACT FACTOR $(2021: 5 \cdot 376)$

OCLC -1276789625 METADATA IF -7.569

Publisher: Frontline Journals

education in 1971, and 1558 in 1972, 1981 in 1973, 1790 in 1974, and 1818 in 1975.

The reclamation of the Karshi deserts officially began on August 26, 1963 (2, p.4).The intention of reclamation of the deserts was directed to develop cotton growing and to carry the cotton to the center. Aiming that in 1963 "Karshistroy" management was organized to reclaim virgin land in Karshi deserts and the assistance of "Glavsredasirsovkhozstroy" was planned in the project. On October 26 of that year the Commission of experts of the State planning Committee of the USSR noted it was expedient to complete reclamation and irrigation work of 200 thousand hectares of virgin land in the Karshi deserts to the end of 1975 with its decree. In order to fulfil that plan completely the Ministers' Council of the USSR adopted the resolution "On developing irrigation and reclamation of the Karshi deserts". In the resolution CC CP of Uzbekistan and the Ministers' Council of Uzbekistan were entrusted the following tasks directly by the Ministers' Council of the USSR, to carry out the construction of the Karshi main canal included pumping stations stretching from Amudarya to Kashkadarya, engineering structures, construction materials and implements industry and construction of housing estates for reclaimers within 1967-1970 $[5, \mathrm{p} .5]$.

In the Karshi deserts more than 220 thousand hectares of land set into agricultural turnover. Particularly, reclamation of the desert progressed after the resolution "On the beginning irrigation and reclamation of the first level of the Karshi deserts" by the Ministers' Council of the USSR on December 7, 1963. According to that resolution, "Karshistroy" management was organized within "Glavsredasirsovkhozstroy" of the USSR Ministry of land-reclamation and irrigation [6, p.50-51]. Those measures were only carried out striving towards the benefit of the Soviet government. As a result, cotton monopoly policy increased again in the territory, and peasants came across with serious danger and difficulties.

In the resolution of the government on the reclamation of the Karshi deserts adopted in 1963, it was noted about the "care" for the transferred people, but it wasn't carried out in time [7, p.66]. As the result of it, cadres disorder increased there. The Soviet government was on 
(ISSN - 2752-7018)

VOLUME 02 ISSUE 01 Pages: 35-42

SJIF IMPACT FACTOR $(2021: 5 \cdot 376)$

OCLC -1276789625 METADATA IF -7.569

\section{Crossref d

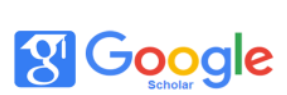

a InDexing 5. WorldCat fô MENDELEY

Publisher: Frontline Journals

bad terms to the situation. Within 1965-1975 the reclaimers of the Karshi deserts paid a particular attention to chief units - to hasten the initial construction of the Karshi main and Ulyanov canals. In the state farms, organized in 1965 in order to reclaim in short time there were about 6,9 thousand families came from highlands of the province, or 31,2 thousand able-bodied people, and 4 thousand of them were machine-operators [8, p.11].

In 1969 the USSR Ministers' Council confirmed the first stage of project on the irrigation and reclamation of that land in the higher zone of the Karshi deserts. According to it, it was necessary to irrigate and reclaim 200 thousand hectares of land. It was determined to organize 43 farms there. 36 of them were cotton growing, and others were 3 horticulture, 2 cattle-breeding and 2 grain-rearing state farms [9, p.55]. 1552 million soums determined to carry out the plan.

On July 251970 Central Committee of CPSU and the Ministers' Council of the USSR adopted the resolution "On hastening irrigation and reclamation work in the Karshi deserts of Uzbekistan SSR". According to the resolution, it was planned to irrigate 300000 hectares to
1980, especially, 85000 hectares of land in the ninth 5-year-term in the Karshi deserts, to grow 100000 tonns of cotton in 1974-1975, and to increase the harvest to 400000 tonns to 1980 [1, p.26].

Corresponding to the resolution of the CC CPSU and USSR Ministers' Council "On hastening irrigation and reclamation work in the Karshi deserts of Uzbekistan SSR" and to decree 383 of CC CP of Uzbekistan and UzSSR Ministers' Council on July 1970 the board of UzSSR Ministry of Utilities adopted decree 43 on August 1970. In the middle of 1970s fore-mentioned institute worked out the second stage project of the Karshi deserts reclamation. It considered complex irrigation and reclamation of 102,1 thousand hectares of land. 12 new cottongrowing, 2 cattle-breeding and 1 horticulture collective farms were planned to organize there and to hold complete reconstruction work in 7 existing farms. In 1973 the first farm - state farm 9 named after Chuli Begimkulov was sent to the Karshi deserts. At the end of 1975, 18 state farms began to rear product. In the spring of 1974, the water of Amudarya ran to the desert through $164 \mathrm{~km}$-branch of the Karshi main canal. 6 
(ISSN - 2752-7018)

VOLUME 02 ISSUE 01 Pages: 35-42

SJIF IMPACT FACTOR $(2021: 5 \cdot 376)$

OCLC -1276789625 METADATA IF -7.569

pumping stations raised water 132 metres in hight. The water of the Amudarya, Kashkadarya and Zarafshan rivers joined [9, p.58].

The USSR Ministers' Council confirmed complex project of the first stage of the Karshi desertsirrigation and reclamation of 200 thousand hectares of land, construction of state farms that total cost was 1 billion 285 million soums [6, p.51-52]. In 1982 virgin state farms of the Karshi deserts sold 245,7 thousand tons of cotton to the state, and 91,5 thousand tons of it was fine-stapled cotton. Since the organizations state farms the farms in virgin land gave state 1 million 561 thousand tons of cotton. It is obvious that the intention of the Soviet government was to consentrate the storage of the Union by developing cotton-growing in the area on grounds of cotton monopoly. This influenced negatively to the lifestyle of the peasants.

In the main projects of economic and social development of the former USSR planned for 1981-1985 and to 1990 it was noted as following: "Reclamation of The Karshi and Jizzakh deserts should continue. 450-465 thousand hectares of irrigating land should be set to use..."[3, p.19]. In reclaimed areas of the
Karshi deserts 6 new districts-Nishon, Ulyanov, Usman Yusupov, Muborak, Bakhoriston and Tolimarjon were organized. The Karshi deserts was noted as a particular unit of XII 5-year term in Main directions project planned to economic and social development of the USSR for 19861990 and to 2000. On grounds of it, "Nowadays the territory of reclaimed land reached about 211 thousand hectares. The state spent 1 billion 146 million roubles for reclamation" [12, p.56.]. As the result of reclamation of the Karshi deserts and Surkhan-Sherabad oasis a new cotton basis was founded in the South of Uzbekistan equal to Ferghana Valley [11, p.54].

\section{Conclusion}

As a conclusion we can say, it is obvious from abov-mentioned information that the Soviet government paid a particular attention to the development of cotton-growing in the Karshi deserts. Nevertheless, those measures brought to the formation of colonial policy named as cotton monopoly by local people. Most of the cotton fetched the center. Cotton monopoly policy caused many bad results in the life of people. 
(ISSN - 2752-7018)

VOLUME 02 ISSUE 01 Pages: 35-42

SJIF IMPACT FACTOR (2021: 5. 376)

OCLC -1276789625 METADATA IF -7.569

\section{REFERENCES}

1. Abdurakhmanova, T. Irrigation of our epoch.Tashkent: Uzbekistan, 1976.-342 p.

2. National archive of Uzbekistan, fund.R-837, list - 2182, volume- 2483.

3. Goibov, R.Development of Karshi desert // Agriculture of Uzbekistan.-1981.-№.2. -P.1920.

4. Goipova, T. Effective use of labour resources in Karshi desert.-Tashkent: Uzbekistan, 1981.$456 \mathrm{p}$.

5. Imomov H., Kholdorov, H. Effectivenes of capital means // Agriculture of Uzbekistan.1986.-№1.-P.56-57.

6. Jalolov, E. Blossoming oasis // Agriculture of Uzbekistan.-1983.-№8.-P.50-51.

7. Karimov, I. Uzbekistan at the approach to Independence.-Tashkent: Uzbekistan, 2011.$567 \mathrm{p}$.

8. Khushvaktov H. Formation of labour resources in the reclamation process of Karshi desert // History of Uzbekistan.-2012.-№3-4,P.66.

9. Kuziboyev, G. Discovered Virgin land // Agriculture of Uzbekistan.-1988.-№8.-P.58.
10. Normukhamedov, A. Courage of a quarter century // Agriculture of Uzbekistan.-1990.№4.-P.55.

11. Ochilov, N. Irrigation and land-reclamation in Uzbekistan (1946-1964).-Tashkent: Fan, 1991.- $445 \mathrm{p}$.

12. Resolution of the Central Committee of Uzbekistan CC and UZSSR Ministers' Committee (RCCUCC).On developing irrigation and reclamation of the Karshi deserts // Agriculture of Uzbekistan.-1967.№7.-P.5-6. 